\title{
Strategic Management: Banking Technology Readiness Analysis in Facing Challenges and Opportunities
}

\author{
Kamaludin \\ Department of Management Faculty of Economics and \\ Business, Bengkulu University \\ Bengkulu, Indonesia \\ E-mail: kamaludinapur@gmail.com
}

\author{
John Tampil Purba \\ Post Graduate Department \\ STIE Pengembangan Bisnis dan Manajemen \\ Jakarta, Indonesia \\ E-mail: jpoerba88@gmail.com
}

\begin{abstract}
Opportunities and challenges are the culture of the people in business arena. Those also happen in the Banking Industry over the world, transforming from the traditional systems into high end technology. Strategic Management is needed in preparing technology readiness (TR) of banks in customerfocused services, with innovative and fast is seen as a major requirement. Addressing the readiness toward innovation and new ideas in TR may be the best place to start. How well the information technology being used familiar, will depend on the readiness of the employees in banks institutions. This study aims to reveal the TR of the employees in using information communications technology in their daily working activities. This study adapted and modified from TR which developed by Parasuraman and Colby. This research conducted at the bank GHB, located in South Jakarta, by taking a sample of 250 employees as randomly. Descriptive analysis and quantitative analysis are used to get some conclusions. The results, employees more optimistic with average value 3.92 and innovativeness with the average value 3.87 in their daily working in the company. Otherwise, in terms of discomfort is in the small value 2.64 and in the insecurity 3.29. In each item and the strategic management will be discussed in the discussion of this paper.
\end{abstract}

Keywords: strategic management, banking, technology readiness, challenges and opportunities.

\section{INTRODUCTION}

The dynamics of the world economy in its influences has reached a new equilibrium directly and indirectly give impact to developments for business of the banking industry. In the highly dynamic macro economy, each nation must be able to identify and recognize problems immediately and make adequate decisions quickly in order to sustain the business, companies and or organizations. Today's banking industries use the high end technology in their day to day activities in in making adequate decisions quickly also in sustaining and giving services to their customers, as their main business in the banking transactions.

As the technology become the main tools in the recent business activities the opinion of Panday, R. and Purba, John T. [1] advances in technology plays an important role in the various activities of human beings, such as business activities, trades, industries, social, and cultural. Almost every human activity requires information. With the advancement of technology, especially information technology is developing rapidly, since it has been found computer and internet development. Development of hardware and software related to information systems is also growing rapidly.

Media also finding information or access the information also varies and growing very rapidly, begin from the development of the hand phone, the hand phone with simple features, up to the hand phone with a varieties of features, the development of minicomputers/laptops, appeared again iPod, gadgets, and development of internet, making information can be obtained anytime and anywhere with ease and quickly. The Information systems Technology use for that development organizations, which are now known as the Information Communication Technology (ICT). Currently ICT has been widely used in every activity of the organization, either partially or as a whole.

As concluded by Bui, Tung X. [2] technology and societal changes are moving the global market rapidly towards a new economic order rooted in e-commerce. Hence, assessing and monitoring the e-readiness of a nation has become an increasing challenge. The rise of Internet access during the past two decades is transforming global trade dynamics. In the line of Bui's conclusion, the Economist [3] reported that today firms of all sizes can take advantage of information and communications technologies (ICT) to conduct trade across international borders. But Internet access and entrepreneurial spirit are only two parts of the equation. For trade to flourish there must also be a favorable policy and regulatory environment. In this report, e-trade readiness refers to the extent to which countries create such an environment to support ICT-enabled commerce across borders. The five factors that determine this environment are the overall investment climate, internet environment, international trading environment, regulatory and legal framework, and e-payments environment. 
A. Scanning of Indonesia Banking Industries among Five ASEAN Countries.

The Indonesian banking industries continues to develop their performance over the region and global industry era. Thus, for opportunities are still open and challenges must be concerned. Setiadi, Edy [4] Indonesia Banking Performance vs. other ASEAN Countries, for the last 3 years, the performance of Indonesia banking industry was better than other ASEAN countries. It has higher Capital Adequacy Ratio and lower Non Performing Loan. The profitability of Indonesia banking industry is better than other ASEAN countries and it will attract foreign bank to expand their businesses in Indonesia as displayed in the following figure 1:
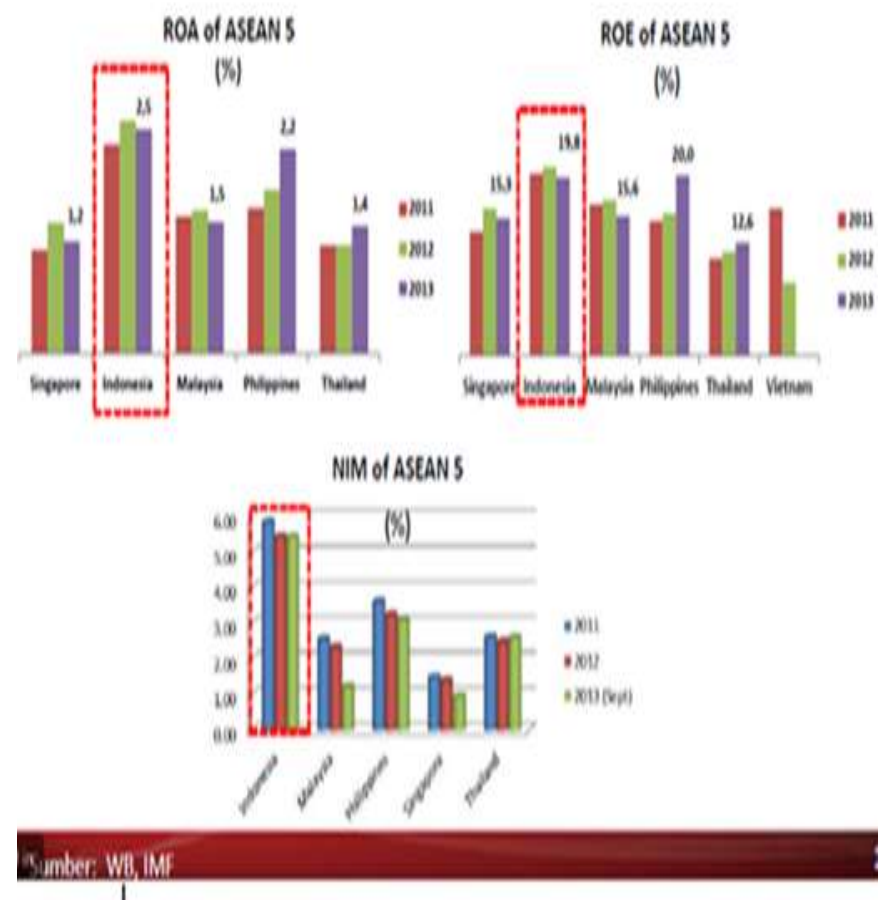

Source: World Bank, IMF

Figure 1. Good Performance of Indonesia Banking Industry.

\section{B. Technology Readiness in Indonesian Banking Industries}

The sample condition of Technology Readiness in Indonesian Banking Industry according the report of Wibisana, Yusuf [5] from PWC Indonesia; easy access to banking needs is ensuring customer can utilize banking services efficiently through a number of different channels is integral to keeping customer happy. Customers are getting used to the convenience and shorter turned around times that online and mobile devices can offer in their daily lives and they are now demanding similar levels of speed and ease of access from banks. Although ATMs have been fastest growing channels in Indonesia in recent years, there have been significant investments in mobile and internet banking by many banks. Despite these advances the largest percentage of bankers surveyed $(39 \%)$ still consider that a convenient and easy accessible branch is most valued by customers. In the figure 2 shows the usage information technology "readiness" going to the growth level, indicated above that; $28 \%$ have strong internet, $22 \%$ ATM machine, only $9 \%$ in mobile banking technology. It means that information system in the financial business like banks realize the usage of technology for efficient and effective in their industries operations, and also they realize their consumers that fully understand their rights and obligations will only materialize given that the supporting technology infrastructure is able to facilitate their developing dynamics.

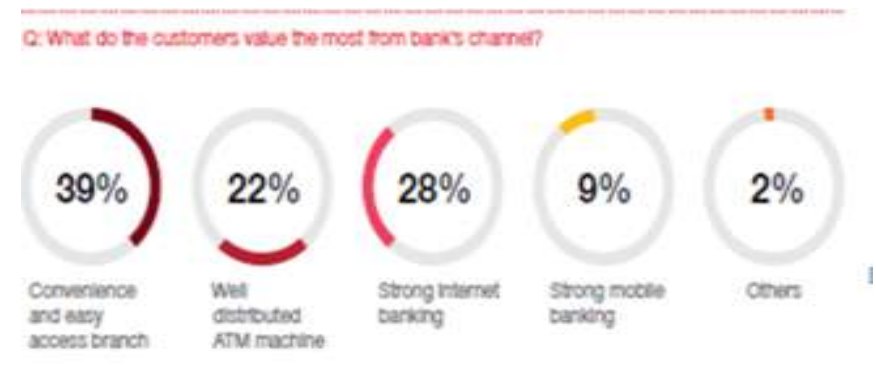

Source: PWC Indonesia; www.pwc.com/id

Figure 2. Indonesian Bank Survey 2013

Thus, for this reason the improvements of banking industry's technology must receive as top priority in the way to the strengthen bank internal management. So, the fast pace development of information technology requires a level playing field in banking activities to enable the global market to be accessible from all corners of the world. This will force us to realign our operational standards in order to survive and to win in the competitive international banking world

The hopes and the suggestions for Indonesian Banking industries shall be managed in effectively and strength in facing the complex business and universal banking as the statement of Central Bank Governor (BI), Abdullah, Burhanudin [6] regarding to a global trend in the banking industry, it can be said that consolidation is under way between almost all ownership of major banking institutions and other financial industry corporations (such as insurance, money market, securities, mutual funds, and other related derivative activities). Over time, this has rapidly become widespread practice, producing a change in the nature of a bank's business from conventional operations to the more complex business of universal banking. The implementation of best practices in good governance and Basel II should become our focus of attention.

It is hoped that when the time comes where the momentum of strengthening shifts to become the momentum of growth, we will be equipped with effective operational capacities which allow us to dynamically move forward in a sustainable manner.

\section{REVIEW OF LITERATURE}

In the banking services also use the Information Technology for the sake of growth, sustainability and innovations as Holland, Lockett, Blackman [7] the combination of new IT, deregulation and globalization ensure that new ideas and innovations spread quickly and break down 
the traditional barriers to entry in the banking industry. This can be seen clearly in the internationalization of retail financial services (including banking) particularly across Europe and the US, the development of novel banking systems such as IBOS and Digicash, and the growth of retailer and automotive companies' activities in what were once traditional bank markets such as deposits and loans.

In the connection to that, Pertiwi, Ana Dewi and Hermana, Budi [8] growth of technology information was very quickly, that make communications through internet have been adopted by business sector as an important tool to give information. The Internet has emerged as a medium of communication of financial reporting information by companies since the mid to late nineties Khan [9]. Companies may not be aware of the potential benefits offered by the web for communication purposes. Lodhia [10]. In line of that argumentation as cited by Purba, John T. [11] ICT gives a lot of contributions in the rapid transformation in global society. The people have to adapt in evolving claims of this trend in order to survive from daily struggles; according to Oyelere, P.B., Laswad, F., \& Fisher, R [12], the development of the Internet as a medium for the dissemination of corporate financial information creates a new reporting environment. Due to the dynamic business world, traditional paper-based corporate reporting is becoming less timely and thus less useful to decision makers, Davey and Homkajohn, [13]. Our inability to make a timely policy responds to external developments, such as rising world oil prices and global imbalances, have often caused us to lose momentum, which brings a higher cost consequences to be borne by the economy.

Purba, John Tampil [14] stated that ICT usage in managing companies and other organizations become a strategic choice of innovation to achieve competitive advantage nowadays. IT becomes main tool to implement corporate sustainability, so the readiness and acceptance of the new technology contributing to organizational effectiveness in running the companies and or organizations. Technology readiness can be viewed as a gestalt resulting from four personality dimensions: optimism, innovativeness, discomfort, and insecurity.

The people's personality inside the organization can be effected by the technology readiness as Parasuraman [15] these personality dimensions affect people's tendency to embrace and use new technologies. In this respect, optimism and innovativeness function as mental enablers, while discomfort and insecurity function as mental inhibitors to accepting new technologies. Explaining and predicting user adoption of new technology has a long his-tory of attention in both academia and practice. While, technology readiness construct can be also seen as the state of mind resulting from a gestalt of mental enablers and inhibitors that collectively determine a person's predisposition toward using new technologies, Lin, Shih, Sher, [16]. Demirci, Ahmet E. and Ersoy, Nezihe F. [17] added that through the research, found there are a number characteristics that having compliance with the acceptance of new technologies or services resulting in interaction through technology.

Thus, the term technology-readiness refers to people's propensity to embrace and use new technologies for accomplishing goals in home life and at work as Parasuraman stated. Lin and Hsieh [18] found that it is critical for firms currently using, or considering using SSTs to address the TR of customers. Lin and Hsieh's results show that the higher technology readiness of the customers, the higher satisfaction and behavioral intentions generated when using self-service technologies. At the measurement level, the Technology Readiness Index (TRI) was developed to measure people's general beliefs and some thinking on technology.

\section{A. Technology Readiness Index (TRI)}

Previous studies show that individuals have different personality and attitudes toward the use of technology Rogers, [19]. Technology readiness effects acceptance of information technology and systems. As described by Parasuraman before developed technology readiness index (TRI) the scale to measure the level of readiness to use technology. TRI is interested in the disposition of using technology, instead of the competency to use it, Parasuraman and Colby [20]). TRI defines four groups of users on the basis of personality traits; optimism, innovativeness, discomfort, and insecurity. Technology Readiness Index defines as follows:

Optimism: A positive belief about technology to increase control, flexibility and efficiency.

Innovativeness: A tendency to be the first using a new technology.

Discomfort: A perception of lack of control over technology and a sense of being overwhelmed by it.

Insecurity: Distrusting technology for security and privacy reasons and skepticism about its ability to work properly.

The relative strength of positive drivers in technology readiness indicates a person's openness towards technology. Optimism and innovativeness are the positive drivers of technology readiness. They encourage individuals to use technological products/services, and to hold a positive attitude towards technology. On the contrary, discomfort and insecurity are the negative attitudes; they make customers reluctant or have less intention to adopt new technology Yen [21]. For clearly view of description the figure 3 below displayed accordingly;

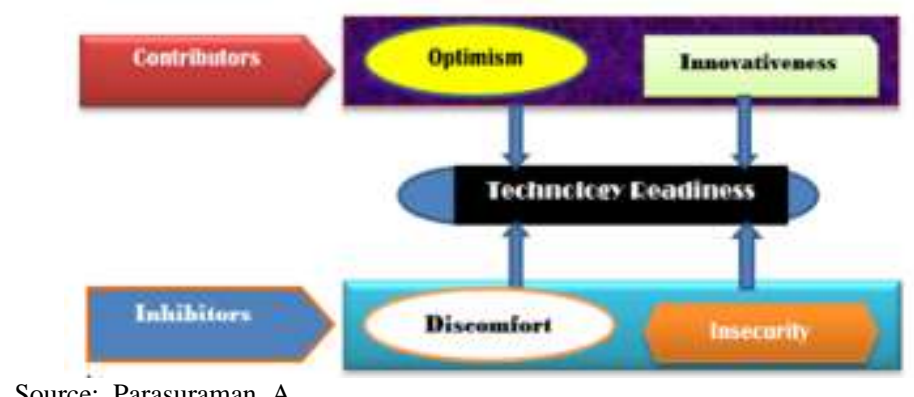

Figure 3. Drivers of Technology Readiess

\section{METHODOLOGY}

In achieving the objective of this study, the researcher uses a quantitative research by exploratory study using survey instrument to the respondents. The instrument's construction 
for in this research is, using questionnaires of Parasuraman's Technology Readiness which firstly modified and adjusted toward Indonesian Banking Industry and GHB bank. These constructs are detailed further into the 36 questions variables of Technology Readiness (TR) in four (4) dimensions, namely technology readiness; Optimism, Innovativeness, Discomfort and Insecurity. In the construction of the questionnaires he used the Likert Scale with 1 until 5 of scaling of measurement. The numbers of respondents in this study were employees of Bank of GHB as many as 250 persons. The organization of this study is located at South Jakarta, Indonesia.

Prior to the analysis, the reliability and validity tests are conducted using SPSS application. From the collecting data then, do the test by using the Pearson correlation coefficient and Cronbach's coefficient. The analysis of Technology Readiness in this study is done descriptively, i.e. analyzing the average value of each variable and the average of each dimension of technology readiness.

\section{RESULTS AND DISCUSSION}

From the data obtained from 250 persons of the respondents, researchers tested the validity and reliability test using Pearson correlation coefficient and Cronbach. Results on the test count as displayed in Table-1, in which each variable in each dimension readines technology has a value of correlation was greater than 0.5 and significant at the 0.01 level. With the results of these tests can be considered that each variable at the level of technology readiness valid. Reliability values for each dimension of technology readiness, demonstrating the value that has been greater than 0.6 , this means that the data obtained is reliable. Thus the data obtained from all respondents are valid and reliable.

\section{TABLE 1 THE COUNT RESULTS OF TESTING THE VALIDITY AND RELIABILITY}

\begin{tabular}{|c|c|c|c|c|c|c|c|}
\hline $\begin{array}{l}\text { Opti- } \\
\text { mism }\end{array}$ & $\begin{array}{l}\text { Pear- } \\
\text { son } \\
\text { Corre- } \\
\text { lation }\end{array}$ & $\begin{array}{l}\text { Inno } \\
\text { vativ } \\
\text { eness }\end{array}$ & $\begin{array}{l}\text { Pear- } \\
\text { son } \\
\text { Correl } \\
\text { ation }\end{array}$ & $\begin{array}{l}\text { Dis- } \\
\text { com- } \\
\text { fort }\end{array}$ & $\begin{array}{c}\text { Pearson } \\
\text { Correla- } \\
\text { tion }\end{array}$ & $\begin{array}{l}\text { Inse- } \\
\text { curity }\end{array}$ & $\begin{array}{l}\text { Pearson } \\
\text { Corre- } \\
\text { lation }\end{array}$ \\
\hline OP1 & $\begin{array}{r}, 618(* *) \\
)\end{array}$ & IN1 & $\begin{array}{r}, 708(* \\
*)\end{array}$ & DIS1 & $\begin{array}{r}, 820(* * \\
)\end{array}$ & INS1 &, $665(* *)$ \\
\hline OP2 & ,581(** & IN2 & $\begin{array}{r}, 735(* \\
*)\end{array}$ & DIS2 & ,860(*** & INS2 &, $549(* *)$ \\
\hline OP3 & $\begin{array}{r}, 646(* * \\
)\end{array}$ & IN3 & $\begin{array}{r}658\left(^{*}\right. \\
*)\end{array}$ & DIS3 & $\begin{array}{r}, 893(* * \\
)\end{array}$ & INS3 &, $472(* *)$ \\
\hline OP4 & $\begin{array}{r}, 581(* * \\
)\end{array}$ & IN4 & $\begin{array}{r}716\left(^{*}\right. \\
*)\end{array}$ & DIS4 & $\begin{array}{r}, 826 * * * \\
)\end{array}$ & INS4 &, $300(* *)$ \\
\hline OP5 & $\begin{array}{r}, 612(* * \\
)\end{array}$ & IN5 & $\begin{array}{r}697 \text { (* }^{*} \\
*)\end{array}$ & DIS5 & $\begin{array}{r}, 799(* * \\
)\end{array}$ & INS5 &, $465(* *)$ \\
\hline OP6 & $\begin{array}{c}\text {,751(** } \\
\text { ) }\end{array}$ & IN6 & $\begin{array}{r}, 580(* \\
*) \\
\end{array}$ & DIS6 & $\begin{array}{r}, 698(* * \\
)\end{array}$ & INS6 &, $657(* *)$ \\
\hline OP7 & $\begin{array}{r}, 774(* * \\
)\end{array}$ & IN7 & $\begin{array}{r}689{ }^{*} \\
*)\end{array}$ & DIS7 & $\begin{array}{r}, 806(* * \\
)\end{array}$ & INS7 &, $478(* *)$ \\
\hline OP8 & $\begin{array}{r}\text {,741(** } \\
\text { (*) }\end{array}$ & & & DIS8 & $\begin{array}{r}\text {,792(** } \\
\text { ( }\end{array}$ & INS8 &, $465(* *)$ \\
\hline$\overline{\text { OP9 }}$ & $\begin{array}{r}, 740(* * *) \\
)\end{array}$ & & & DIS9 & $\begin{array}{r}, 860(* * \\
)\end{array}$ & INS9 &, $531(* *)$ \\
\hline OP10 & $\begin{array}{r}\text {,702(** } \\
\text { (*) }\end{array}$ & & & $\begin{array}{l}\text { DIS1 } \\
0\end{array}$ & $\begin{array}{r}, 880(* * \\
)\end{array}$ & & \\
\hline $\begin{array}{l}\text { Alpha } \\
=\end{array}$ & 8671 & Alph & ,7923 & $\begin{array}{c}\text { Alph } \\
\mathrm{a}=\end{array}$ & ,9482 & $\begin{array}{c}\text { Alpha } \\
=\end{array}$ & ,7850 \\
\hline
\end{tabular}

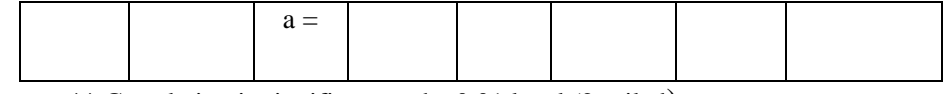

** Correlation is significant at the 0.01 level (2-tailed).

* Correlation is significant at the 0.05 level (2-tailed).

\section{A. Findings and Discussions}

Technology readiness level for optimism dimensions, the average value are shown in table 2. The mean of optimism's score is 3.92, it is shown that the average values are very high, meaning that bank's employees of GHB are quite optimistic in the usage of ICT technologies in the giving services to the customers. Because they have very high positive view of technology and belief that offers people increased controlled, flexibility, and efficiency in their point of views over working activities. From that captures shown in generally of them have positive feelings about technology readiness.

TABLE 2 THE AVERAGE VALUE OF THE VARIABLE IN THE DIMENSIONS OF OPTIMISM

\begin{tabular}{|c|c|c|c|}
\hline & Description variables & Mean & $\begin{array}{c}\text { Std. } \\
\text { Deviation }\end{array}$ \\
\hline OP1 & $\begin{array}{l}\text { Technology gives people more } \\
\text { control over their daily lives }\end{array}$ & 3,92 & ,820 \\
\hline $\mathrm{OP} 2$ & $\begin{array}{l}\text { Products/services that use new } \\
\text { technologies are convenient to } \\
\text { use }\end{array}$ & 3,64 &, 825 \\
\hline OP3 & $\begin{array}{l}\text { I like the idea of doing business } \\
\text { via computers because I'm not } \\
\text { limited to regular business hours. }\end{array}$ & 3,64 & ,908 \\
\hline $\mathrm{OP} 4$ & $\begin{array}{l}\text { I prefer to use the most advanced } \\
\text { technology available. }\end{array}$ & 4,12 & ,637 \\
\hline OP5 & $\begin{array}{l}\text { I like computer programs that } \\
\text { allow me to tailor things to fit my } \\
\text { own needs. }\end{array}$ & 4,12 & ,803 \\
\hline OP6 & $\begin{array}{l}\text { Technology makes me more } \\
\text { efficient in my occupation }\end{array}$ & 3,90 & ,943 \\
\hline OP7 & $\begin{array}{l}\text { I find new technologies to be } \\
\text { mentally stimulating. }\end{array}$ & 4,04 & ,839 \\
\hline OP8 & $\begin{array}{l}\text { Technology gives me more } \\
\text { freedom of mobility. }\end{array}$ & 4,06 & ,779 \\
\hline OP9 & $\begin{array}{l}\text { Learning technology can be as } \\
\text { rewarding as the technology } \\
\text { itself. }\end{array}$ & 3,94 &, 815 \\
\hline OP10 & $\begin{array}{l}\text { I feel confident that machines } \\
\text { will follow through with what I } \\
\text { instructed them to do. }\end{array}$ & 3,79 &, 824 \\
\hline $\begin{array}{l}\text { Ave- } \\
\text { rage } \\
\text { value }\end{array}$ & & 3,92 & \\
\hline
\end{tabular}

The average value of innovativeness as shown in the table 3 below is 3.87 , "it shows that there is a tendency quite high to 
be the technology pioneer and to be the leader". This dimension generally measures to "what degree of individuals perceive of themselves as forefront in technology readiness". It is shown that there is a fairly high willingness of the employees to be always ready in adopting the latest and advanced technology in the organization.

TABLE 3 THE AVERAGE VALUE OF THE VARIABLE IN DIMENSION INNOVATIVENESS.

\begin{tabular}{|c|c|c|c|}
\hline & Innovativenss-dimension & Mean & $\begin{array}{c}\text { Std. } \\
\text { Deviation }\end{array}$ \\
\hline IN1 & $\begin{array}{l}\text { Other people come to me for } \\
\text { advice on new technologies }\end{array}$ & 3,99 & ,649 \\
\hline IN2 & $\begin{array}{l}\text { It seems my friends are learning } \\
\text { more about the newest } \\
\text { technologies than I am. }\end{array}$ & 3,94 & 674 \\
\hline IN3 & $\begin{array}{l}\text { In general, I am among the first in } \\
\text { my circle of friends to acquire } \\
\text { new technology when it appears }\end{array}$ & 3,97 & 639 \\
\hline IN4 & $\begin{array}{l}\text { I can usually figure out new high- } \\
\text { tech products and services } \\
\text { without help from others. }\end{array}$ & 3,86 & ,649 \\
\hline IN5 & $\begin{array}{l}\text { I keep up with the latest } \\
\text { technological developments in my } \\
\text { areas of interest. }\end{array}$ & 3,82 & ,919 \\
\hline IN6 & $\begin{array}{l}\text { I enjoy the challenge of figuring } \\
\text { out high-tech gadgets }\end{array}$ & 3,78 & ,981 \\
\hline IN7 & $\begin{array}{l}\text { I find I have fewer problems than } \\
\text { other people in making technology } \\
\text { work for me. }\end{array}$ & 3,72 &, 892 \\
\hline $\begin{array}{l}\text { Ave- } \\
\text { rage } \\
\text { value }\end{array}$ & & 3.87 & \\
\hline
\end{tabular}

The average value of the discomfort in the dimension table-4 is in the level of 2.64, it indicates a lack of perceived control over technology and feeling overwhelmed by this dimension is quite low. The actions of the respondents in this dimension generally experience a sense of fear and worries people when confronted with technology. GHB bank employees seem to have fears and as the experience of the people in general when using technology, which is quite low, however, the bank employee is not awkward in the use of technology in the works.

TABLE 4 THE AVERAGE VALUE OF THE VARIABLE IN THE DIMENSION OF DISCOMFORT.

\begin{tabular}{|l|l|c|c|}
\hline & \multicolumn{1}{|c|}{ Discomfort -dimension } & Mean & $\begin{array}{c}\text { Std. } \\
\text { Deviation }\end{array}$ \\
\hline DIS1 & $\begin{array}{l}\text { Technical support lines are not helpful } \\
\text { because they don't explain the things } \\
\text { in terms I understand. }\end{array}$ & 2,65 &, 730 \\
\hline DIS2 & $\begin{array}{l}\text { Sometimes, I think that technology } \\
\text { systems are not designed for use by } \\
\text { ordinary people. }\end{array}$ & 2,66 &, 827 \\
\hline DIS3 & $\begin{array}{l}\text { There is no such thing as a manual for } \\
\text { a high-tech product or service that's } \\
\text { written in plain language. }\end{array}$ & $\begin{array}{l}\text { When I get technical support from a } \\
\text { provider of a high-tech product or } \\
\text { service, I sometimes feel as if I am } \\
\text { taken advantage of by someone who } \\
\text { knows more than I do }\end{array}$ & 2,66 \\
\hline
\end{tabular}

\begin{tabular}{|l|l|c|c|}
\hline DIS5 & $\begin{array}{l}\text { If I buy a high-tech product or service, } \\
\text { I prefer to have the basic model over } \\
\text { one with a lot of extra features. }\end{array}$ & 2,62 &, 720 \\
\hline DIS6 & $\begin{array}{l}\text { It is embarrassing when I have trouble } \\
\text { with a high-tech gadget while people } \\
\text { are watching. }\end{array}$ & 2,58 &, 736 \\
\hline DIS7 & $\begin{array}{l}\text { There should be caution in replacing } \\
\text { important people-tasks with } \\
\text { technology because new technology } \\
\text { can break down or get disconnected }\end{array}$ & 2,64 &, 743 \\
\hline DIS8 & $\begin{array}{l}\text { Many new technologies have health or } \\
\text { safety risks that are not discovered } \\
\text { until after people have used them. }\end{array}$ & 2,66 &, 807 \\
\hline DIS9 & $\begin{array}{l}\text { New technology makes it too easy for } \\
\text { governments and companies to spy on } \\
\text { people. }\end{array}$ & 2,64 &, 781 \\
\hline DIS10 & $\begin{array}{l}\text { Technology always seems to fail at the } \\
\text { worst possible time. }\end{array}$ & 2,66 &, 817 \\
\hline $\begin{array}{l}\text { Avera } \\
\text { ge } \\
\text { value }\end{array}$ & \multicolumn{2}{|l}{} & \\
\hline
\end{tabular}

As shown in table 5 below; the average value of the dimension of Insecurity there with the average value of 3.29. It means "distrust of technology and Skepticism about its ability to work properly" it shows that the presence of skepticism and distrust their properties at these dimensions remained at a fairly high level. In this case distrust and skeptic nature of bank employees are at a high enough level, when dealing in the use of advanced and new technology.

TABLE 5 THE AVERAGE VALUE OF THE VARIABLE IN THE DIMENSIONS OF INSECURITY

\begin{tabular}{|c|c|c|c|}
\hline & Insecurity-dimension & Mean & $\begin{array}{c}\text { Std. } \\
\text { Deviation }\end{array}$ \\
\hline INS1 & $\begin{array}{l}\text { The human touch is very important } \\
\text { when doing business with a } \\
\text { company. }\end{array}$ & 3,26 & 1,017 \\
\hline INS2 & $\begin{array}{l}\text { When I call a business, I prefer to } \\
\text { talk to a person rather than a } \\
\text { machine. }\end{array}$ & 3,51 & 1,080 \\
\hline INS3 & $\begin{array}{l}\text { If I provide information to a machine } \\
\text { or over the Internet, I can never be } \\
\text { sure it really gets to the right place. }\end{array}$ & 3,05 & 1,036 \\
\hline INS4 & $\begin{array}{l}\text { I do not consider it safe giving out a } \\
\text { credit card number over a computer. }\end{array}$ & 3,05 & 1,036 \\
\hline INS5 & $\begin{array}{l}\text { I do not consider it safe to do any } \\
\text { kind of financial business online. }\end{array}$ & 3,04 & 1,031 \\
\hline INS6 & $\begin{array}{l}\text { I worry that information I send over } \\
\text { the Internet will be seen by other } \\
\text { people. }\end{array}$ & 3,42 & 1,074 \\
\hline INS7 & $\begin{array}{l}\text { I do not feel confident doing business } \\
\text { with a place that can only be reached } \\
\text { online. }\end{array}$ & 3,49 & 1,061 \\
\hline INS8 & $\begin{array}{l}\text { Any business transaction I do } \\
\text { electronically should be confirmed } \\
\text { later with something in writing. }\end{array}$ & 3,49 & 1,058 \\
\hline INS9 & $\begin{array}{l}\text { Whenever something gets auto- } \\
\text { mated, I need to check carefully that } \\
\text { the machine or computer is not } \\
\text { making mistakes }\end{array}$ & 3,29 & 1,052 \\
\hline $\begin{array}{l}\text { Ave- } \\
\text { rage } \\
\text { value }\end{array}$ & & 3.29 & \\
\hline
\end{tabular}




\section{B. Strategic Management Proposed for Technology Readiness}

Having regarded to the above discussion and by considering the long-term and strategic of the Technology Readiness, in facing the opportunities and challenges; the authors recommend the Proposed Strategic Management for Technology Readiness to the bank management as follows:

1. In the era of globalization the top management of the bank in which this company is a sizeable banking business in Indonesia is always required to be alert and pay attention to macro-economic environments, technological development and human resources readiness in the work environment of the organization.

2. The presence of information and communication technology (ICT) in the banking industry is a challenge and an opportunity as well as the dynamics of the global banking business. Therefore, willing or unwilling, like or don't like the adaptation shall be done for the sake of the survival of the company. For technology readiness meant, the bank management must provide education and training gradually to all employees associated with these technologies.

3. To address concerns of skeptical, and fears of employees to new technology and advised the directorate of human resources give special attention so that the competent trainer can provide enough space and time to the participants training in recognizing and practice to be able to master it.

4. Top management of the bank organizations should truly understand that technology is part of the life banking organizations throughout of national and international. Therefore, the management should provide motivation to employees in the use of new technologies all the time.

5. For the sustainable development and growth of the organization authors recommended that all shareholders and top management must also keep the budget in investment technology readiness for all employees of the organization involved in the organization.

\section{CONCLUSIONS}

The result in table 3 is in the level of 3,87, which means there is a tendency quite high to be a technology pioneer and to be the leader but the other dimensions of the Technology Readiness, according to the respondents, there are still a number of obstacles in this banking company surveyed. For the sake of banking organization sustainability and customers' protection also loyalty, continuous education and training for the employees is required to and intensify to use of new technology. In the era of strong and hyper competition especially in the national and global banking industries the adequacy of quality, quantity of employees, the human resources development, in the inside organization is required.

Thus, it is a compulsory program investment for them in facing the Technology Readiness and enhancing the opportunities and challenges. Integrated management strategy for human resource and human capital development and technology readiness as well is required, for short the term and for the long term.

\section{References}

[1] Panday, R. and Purba, J. T. "Lecturers and Students Technology Readiness in implementing Services Delivery of Academic Information System in Higher Education Institution : A Case Study. Springer books". http://link.springer. com/ chapter/. Doi: 10.1007\%2F978-3-662-467428_49\#. pp-539-550. 2015.

[2] Bui, Teng X "A framework for measuring national e-readiness". International Journal Electronic Business, 2003, Vol. 1, No. 1. http://www.cob.calpoly.edu / ijeb/2. pdf. Accessed on January, 21st, 2015

[3] The Economist." The G20 e-Trade Readiness Index Commissioned by An Economist Intelligence Unit report". The Economist Intelligence Unit Limited. 2014, http://www.economistinsights.com/countries-tradeinvestment/analysis/g20-e-trade-readiness-index-0. Accessed on December, 11, 2014

[4] Setiadi, Edy. "AEC 2015: Cross Border Supervision and Challenges to Unleash Indonesia Sharia Banking Potential”. Otoritas Jasa Keuangan Seminar (OJK) Presentation in Bandung, December 2nd, 2014.

[5] Wibisana, Y.'Indonesian Banking Survey. PWC Indonesia". http://www.pwc. com/id/en/publications/assets/pwc-indonesia-bankingsurvey-2014.pdf. 2014

[6] Abdullah, B. "Managing the banking industry within the new dynamic of the Indonesian economy". Speech by Mr Burhanuddin Abdullah, Governor of Bank Indonesia, at the Annual Banker's Dinner, Jakarta, 13th January 2006.

[7] Holland, Christopper P., et al. "The Impact of Globalisation and Information Technology on the Strategy and Profitability of the Banking Industry". Proceedings of The Thirtieth Annual Hawaii International Conference on System Sciences. 1997, ISBN 0-8186-7862-3/97/IEEE.

[8] Pertiwi, Ana D. and Hermana, B. "Comparing Internet Financial Reporting Index Between Bank and Non-Bank in Indonesia”. Journal of Internet Banking and Commerce. August 2nd. 2013, vol. 18, no. 2.

[9] Khan, T. "Internet Financial Reporting: Disclosure about Companies on The Website". Journal of Business Systems, Governance, and Ethics, 2007, 2(2), pp. 57-46.

[10] Lodhia, S.K. "The World Wide Web and Its Potential for Corporate Environmental Communication: A Study into Present Practices in the Australian Minerals Industry". The International Journal of Digital Accounting Research. 2006, 6(11), 65-94

[11] Purba, J. T. and Panday, R."Innovation Strategy Services Delivery: An Empirical Case Study of Academic Information Systems in Higher Education Institution”. Springer books. http://link.springer.com/chapter. DOI. 10.1007-2F978-3-662-46742-8_4-1. 2015, pp.514-525.

[12] Oyelere, P.B., P.B., Laswad, F., \& Fisher, R. "Corporate Financial Reporting: Firm Charac-teristics and The Use Of The Internet As A Medium Of Communication". Commerce Division Discussion Paper, (81). 2000,. http://researcharchive.lincoln.ac.nz/dspace/bitstream/10182/ 549/1/cd_dp_81.pdf. Accessed on July 22nd, 2014

[13] Davey, H. \& Homkajohn, K. "Corporate Internet Reporting: An Asian Example. Problem and Perspective in Management". Problems and Perspectives in Management, 2004, vol. 2, 211-227.

[14] Purba, J. T. "Strategic Innovation through Technology Readiness Readiness and Acceptance in Implementing ICT for Corporate Sustainability". [12th International annual symphosium on management, March, 13th-15th, 2015, Makasar, Sulawesi, Indonesia].

[15] Parasuraman, A. "Technology Readiness Index (TRI): A Multiple-Item Scale to Measure Readiness to Embrace New Technologies". Journal of Service Research, 2000, Vol.2(4): pp. 307-320.

[16] Lin, Chien-Hsin, Shih, Hsin-Yu, and Sher Peter J. "Integrating Technology Readiness into Technology Acceptance: The TRAM Model”. Psychology \& Marketing,. Vol.24(7): 641-657. 2007

[17] Demirci, Ahmet E. and Ersoy, Nezihe F. "Technology Readiness for Innovative High-Tech Products: How Consumers Perceive and Adopt New Technologies". 2007. http://isletme.anadolu.edu. tr/media/ articles/dem.irci_ersoy01.pdf. Accessed on November 30th, 2014

[18] Lin, J.C. and Hsieh, P.L. "The Role of Technology Readiness in Customers' Perception and Adoption of Self-Service Technologies". 
International Journal of Service Industry Management, ,Vol.17(5): 497517. 2006

[19] Rogers, Everett M. Diffusion of Preventive Innovations. Addictive Behaviors, Vol.27(6): 989-993. 2002.

[20] Parasuraman, A., \& Colby, C. L "Technoready marketing: How and why your customers adopt technology". New York: Free Press. 2001.

[21] Yen, H.R. "An attribute-based model of quality satisfaction for internet self-service technology", Serv. Ind. J., 25(5), pp. 641-659.

Accessed on January, 21st, 2015 